\title{
Nutrient Composition and Sensory Profile of Differently Cooked Green Leafy Vegetables
}

\section{A. Kala \& Jamuna Prakash}

To cite this article: A. Kala \& Jamuna Prakash (2004) Nutrient Composition and Sensory Profile of Differently Cooked Green Leafy Vegetables, International Journal of Food Properties, 7:3, 659-669, DOI: $10.1081 / J F P-200033079$

To link to this article: https://doi.org/10.1081/JFP-200033079

\section{(2) Copyright Taylor and Francis Group, LLC}

曲 Published online: 06 Feb 2007.

Submit your article to this journal

Џll Article views: 865

Q View related articles $₫$

4 Citing articles: 22 View citing articles 지 
INTERNATIONAL JOURNAL OF FOOD PROPERTIES

Vol. 7, No. 3, pp. 659-669, 2004

\title{
Nutrient Composition and Sensory Profile of Differently Cooked Green Leafy Vegetables
}

\author{
A. Kala and Jamuna Prakash* \\ Department of Studies in Food Science and Nutrition, \\ University of Mysore, Manasagangotri, Mysore, India
}

\begin{abstract}
Four green leafy vegetables commonly consumed in South India were selected for the study. They were subjected to three different methods of cooking namely, conventional, pressure, and microwave cooking. Proximate composition, vitamins (ascorbic acid and $\beta$-carotene), mineral content (calcium, phosphorus, and iron), and in vitro available iron of the raw and cooked samples were estimated. The cooked samples were further subjected to sensory analysis. The results showed that the nutrient content of each green leafy vegetable was distinct and spinach was comparatively a poor source of all nutrients. Cooking caused a significant difference only in the ascorbic acid and $\beta$-carotene content of the greens. No significant difference was observed in the nutrient content due to the three different methods of cooking adopted. Results of the sensory test revealed that color was the only attribute that varied to a large extent due to cooking. Color of pressure cooked greens was considered inferior to conventionally cooked and microwave cooked samples. The sensory attributes of microwave cooked greens were similar to the conventionally cooked samples.
\end{abstract}

*Correspondence: Jamuna Prakash, Department of Studies in Food Science and Nutrition, University of Mysore, Manasagangotri, Mysore-570 006, India; E-mail: jampr55@hotmail. com. 
Key Words: Carotenoids; Conventional cooking; Microwave cooking; Dietary fiber; In vitro available iron; Nutritional composition; Sensory attributes.

\section{INTRODUCTION}

Vegetables form a considerable part of an Indian diet, which is basically vegetarian. The composition and nutrient content of the vegetables vary widely depending on the part of the plant used as food. ${ }^{[1]}$ Generally, vegetables are considered to contribute appreciable amounts of vitamins and minerals but when compared with other groups of vegetables, green leafy vegetables are known to be exceptionally rich in minerals, $\beta$-carotene ${ }^{[2]}$ and are also a good source of dietary fiber and antioxidants. ${ }^{[3,4]}$ It is well established that common cooking methods generally do not lead to any macronutrient (carbohydrate, protein, and fat) or mineral losses but vitamins especially, water soluble and heat labile vitamins are the most vulnerable. The amount of ascorbic acid in plant tissues however, is known to vary tremendously and in green leafy vegetables the age of the leaf is also known to affect the ascorbic acid content. ${ }^{[5]} \beta$-carotene content of greens is also known to depend on various factors such as species, genetic variation, and post harvest losses ${ }^{[6]}$ Green leafy vegetables are also reported to contribute significant amount of protein $^{[7,8]}$ but their availability is limited due to the presence of nondigestible fiber to which protein is bound. ${ }^{[9]}$ The consumption of green leafy vegetables is generally low probably due to its unattractive organoleptic properties such as grassy flavors and odors as stated by Friedman. ${ }^{[7]}$

Microwave cooking is relatively new for household use and there is limited information on the effects of microwave cooking on nutrient as well as sensory attributes of green leafy vegetables. Hence, the present study aimed at comparative evaluation of nutrient composition and sensory profile of green leafy vegetables cooked by three different methods namely, conventional boiling, pressure cooking, and microwave cooking. Raw samples from the same batch were also analyzed which served as controls.

\section{MATERIALS AND METHODS}

Four commonly consumed fresh greens namely, Amaranth (Amaranthus gangeticus), Kilkeerai (Amaranthus tricolor), Shepu (Peucedanum graveolens), and Spinach (Spinacia oleracea) were purchased from a local market on the day of processing. They were cleaned and washed thoroughly under running water followed by distilled water and spread out on dry filter papers to remove the surface moisture. The greens were then cut evenly and divided into four equal parts, of which one part (raw) served as the control and the other three parts were subjected to the three different cooking methods namely, (i) conventional cooking (boiling, covered), (ii) pressure cooking (15lbs), and (iii) microwave cooking (covered, using high power only). The nutrients analyzed were moisture, protein, ${ }^{[10]}$ total ash, ether 
extract, iron, phosphorus, ${ }^{[11]}$ total dietary fiber, ${ }^{[12]}$ calcium, ${ }^{[13]}$ in vitro available iron measured as ionizable iron, ${ }^{[14]}$ ascorbic acid, and $\beta$-carotene. ${ }^{[15]}$ All the analysis was carried out in duplicate for two separate batches of green leafy vegetables. The sensory attributes were analyzed using ranking test ${ }^{[16]}$ and Qualitative Descriptive Analysis (QDA). ${ }^{[1]}$ The panel members for ranking test comprised of 20 postgraduate students of the Institution. Based on the performance in the ranking test, 10 best panelists were selected for QDA. Nutrient analysis results were analyzed statistically using ANOVA. Sensory analysis data was analyzed using the standard table for ranking test ${ }^{[16]}$ and using mean and SD (standard deviation) for QDA.

\section{RESULTS AND DISCUSSION}

The conditions followed for cooking greens presented in Table 1 show that the water required for cooking in pressure cooker and in microwave oven method was lesser than that required for conventional cooking. Microwave cooking of spinach did not require the addition of water as observed earlier by Eheart and Gott ${ }^{[18]}$ and Kylen et al. ${ }^{[19]}$ Pressure cooking required the least amount of time followed by microwave method and then by conventional method. The cooked weight of spinach decreased to a considerable extent in all the three variations. The amount of weight gained due to cooking however, varied with the type of green leafy vegetable irrespective of the water added or the time taken.

The proximate composition of the raw and cooked greens is presented in Table 2. The moisture content of the raw greens ranged from 90.4 to $94.7 \%$. Shepu,

Table 1. Cooking conditions of green leafy vegetables (per $300 \mathrm{~g}$ of edible portion).

\begin{tabular}{llccc}
\hline \multirow{2}{*}{ Vegetable } & Variations & $\begin{array}{c}\text { Water added } \\
(\mathrm{ml})\end{array}$ & $\begin{array}{c}\text { Time taken } \\
(\mathrm{min})\end{array}$ & $\begin{array}{c}\text { Cooked weight } \\
(\mathrm{g})\end{array}$ \\
\hline \multirow{2}{*}{ Amaranth } & Con & 100 & 22 & 305 \\
& Pre & 85 & 9 & 325 \\
\multirow{5}{*}{ Kilkeerai } & Mic & 85 & 14 & 290 \\
& Con & 120 & 18 & 310 \\
& Pre & 85 & 8 & 330 \\
\multirow{5}{*}{ Shepu } & Mic & 90 & 10 & 300 \\
& Con & 175 & 21 & 306 \\
& Pre & 110 & 8 & 310 \\
& Mic & 145 & 10 & 295 \\
& Con & 40 & 12 & 250 \\
& Pre & 40 & 6 & 255 \\
& Mic & - & 8 & 265 \\
\hline
\end{tabular}

Values are mean of two batches.

Con-conventionally cooked; Pre-pressure cooked; Mic-microwave cooked. 


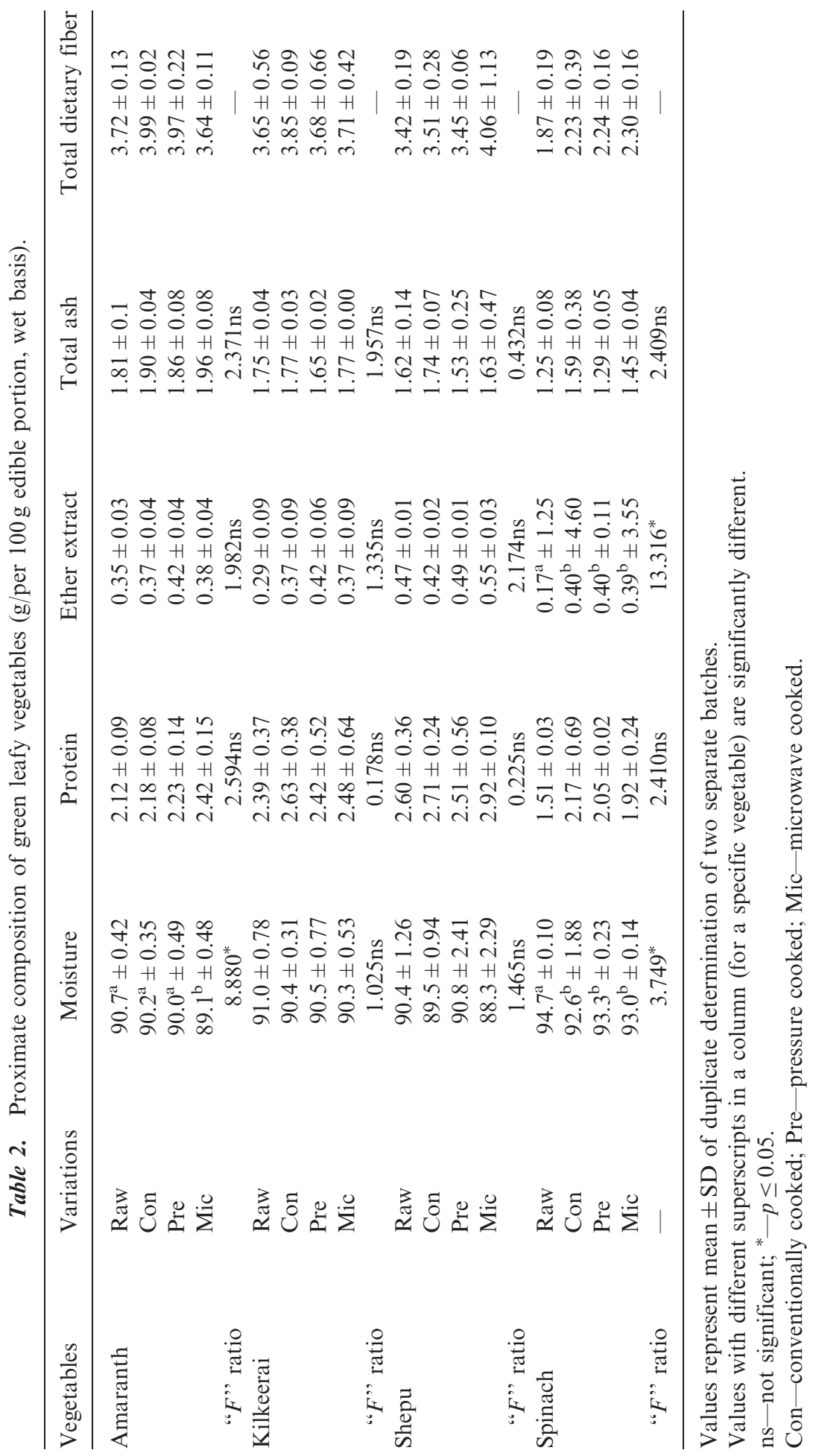


amaranth, and kilkeerai were similar with slightly lower moisture content compared to spinach. Noble and Hanig ${ }^{[20]}$ showed that moisture content of spinach varied with lots i.e., from around $87.7-90.1 \%$. Cooking of green leafy vegetables in general resulted in moisture loss. It was however, significant $(p \leq 0.05)$ only between the raw and the microwave cooked spinach and amaranth. The overall comparison of greens showed that microwave cooked samples lost $10-12 \%$ more moisture. Klein et al. ${ }^{[21]}$ and Kylen et al. ${ }^{[19]}$ have also reported weight loss in microwave cooked and conventionally cooked spinach. The protein content of the raw greens was almost similar in amaranth, kilkeerai, and shepu $(2.12-2.60 \mathrm{~g}$ per $100 \mathrm{~g})$ with spinach containing least amount $(1.51 \mathrm{~g}$ per $100 \mathrm{~g})$. Cooking caused an insignificant $(P \geq 0.05)$ increase in the protein content of all the greens which was due to greater moisture loss. The ether extract of raw greens (Table 2) ranged from $0.17 \mathrm{~g}$ in spinach to $0.47 \mathrm{~g}$ in shepu. Amaranth and kilkeerai had intermediate amount of 0.35 and $0.29 \mathrm{~g}$ respectively. Gopalan et al. ${ }^{[2]}$ also reported a large variation in the ether extracts of amaranth tender, which ranged from 0.5 to $2.69 \%$ in dry matter. Comparison between the ether extracts of raw and cooked sample showed that the cooked samples had greater amounts of ether extract. This increase may be due to greater extractability on cooking of not only fat but also certain other fat-soluble substances such as pigments. ${ }^{[23]}$ The total dietary fiber (TDF), content of raw greens ranged from 1.87 to $3.72 \mathrm{~g}$. TDF content of spinach by Uppsala method A $(2.2 \mathrm{~g} / 100 \mathrm{~g}$ fresh $)$ and AOAC, enzymatic method $\left(2.6 \mathrm{~g} / 100 \mathrm{~g}\right.$ fresh) however, has been reported to be greater. ${ }^{[24]}$ Cooking caused an insignificant increase in the TDF content of all greens except pressure cooked kilkeerai and shepu. The slight increase in the fiber content may probably be due to hydration or polymerization of its fractions. ${ }^{[25]}$ The total ash content of greens varied to a less extent ranging from 1.25 to $1.81 \mathrm{~g}$ (Table 2). Neither cooking nor the different cooking methods caused any significant difference in mineral content probably due to their greater stability. However, an insignificant loss in pressure cooked samples may be due to the soluble mineral salts of phosphorus, potassium, sodium, or iron. ${ }^{[2]}$

The minerals and vitamins analyzed were calcium, phosphorus, iron, ionizable iron, and ascorbic acid and $\beta$-carotene respectively. The results for $100 \mathrm{~g}$ of edible portion are presented in Table 3, which show that among minerals, calcium content varied to a large extent i.e., from $38-55 \mathrm{mg}$ in spinach to $182-195 \mathrm{mg}$ in amaranth. Significant increase in the calcium content of cooked samples of spinach was due to greater moisture loss on cooking. The phosphorus content of the raw and cooked greens was as follows: kilkeerai $-60-68 \mathrm{mg}$ followed by amaranth and shepu $-40-53 \mathrm{mg}$, and spinach-26-32 mg/100 g. The values reported by Gopalan et al. ${ }^{[22]}$ for raw spinach and shepu were comparable. The total iron content of raw greens ranged from $3.0 \mathrm{mg}$ in shepu to $8.7 \mathrm{mg}$ in amaranth. The values obtained in the present study are lower than those reported by Gopalan et al. ${ }^{[22]}$ and higher than those reported by Chawla et al. ${ }^{[26]}$ The iron content of greens is however, known to be influenced due to soil fortification, ${ }^{[27]}$ growth conditions, difference in variety or species. ${ }^{[28]}$ Cooking caused a significant difference $(p \leq 0.05)$ only in the total iron content of shepu. Calculation on dry basis showed that this difference was only due to low moisture content in cooked shepu. Raw greens contained significantly $(p \leq 0.05)$ greater amounts of ionizable iron than the respective cooked ones. 


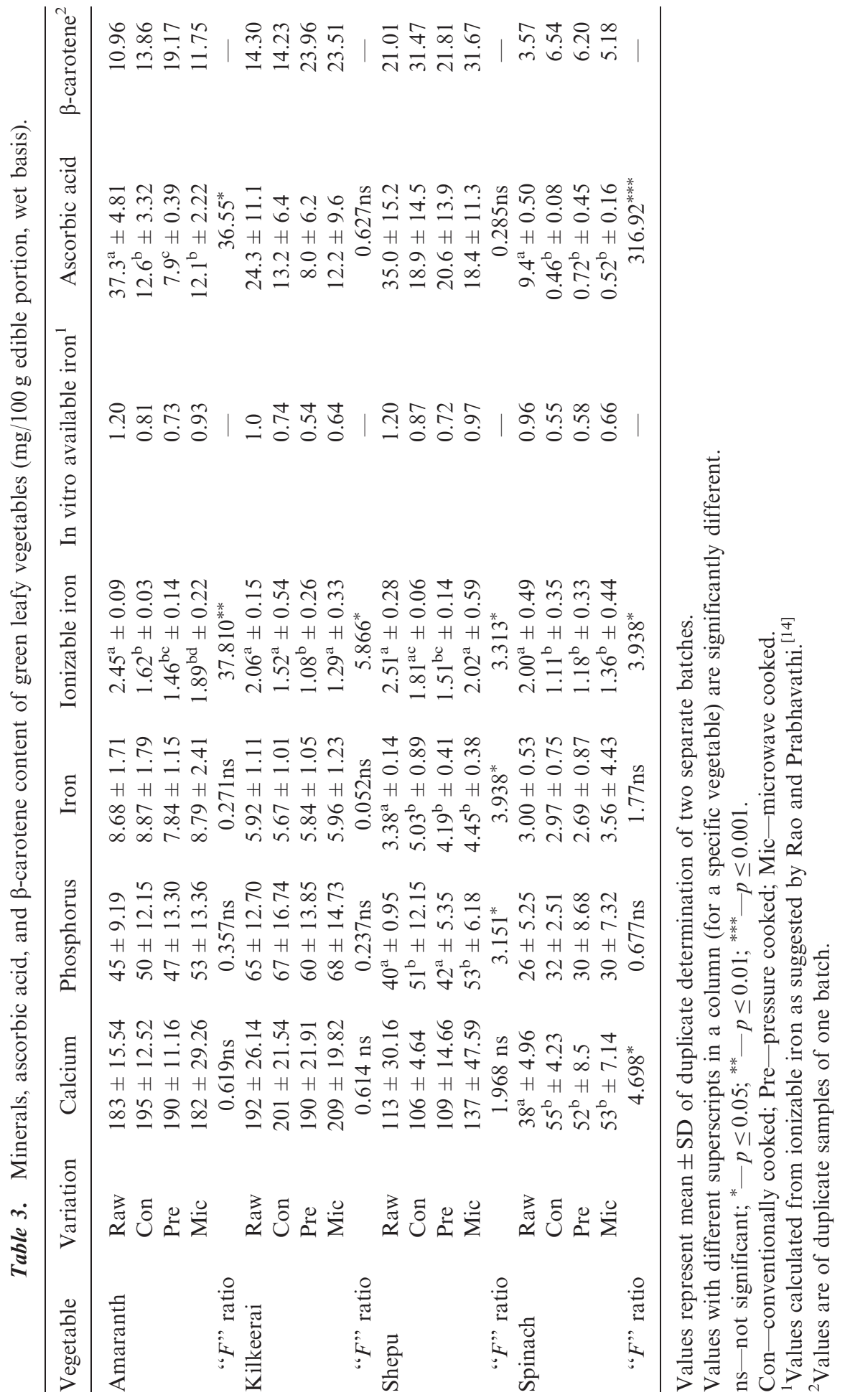


Cooking methods on the whole caused a loss of around $20-48 \%$ of ionizable iron. The in vitro available iron was derived as suggested by Rao and Prabhavathi. ${ }^{[14]}$ The percent in vitro availability of iron from cooked greens was in the range of $9-14 \%$. The availability from shepu and amaranth was greater than those reported by Chawla et al. ${ }^{[26]}$ and Rao and Prabhavathi ${ }^{[14]}$ respectively. Hence, from the above studies it may be concluded that the iron availability from greens depend on many other factors such as presence of oxalates, phytate, fiber or polyphenols ${ }^{[26]}$ and the total iron content alone cannot form the basis to consider a particular green leafy vegetable to be a rich source of iron. The ascorbic acid content of the raw green ranged from 9.4-37.0 mg. Cooking irrespective of the method caused considerable loss of ascorbic acid in all greens. The extent of loss however varied with the greens. The percent loss was least in shepu with $41-47 \%$ and highest in spinach with $92-95 \%$. The extent of loss however was similar in conventionally and microwave cooked greens. The $\beta$-carotene content of the raw greens ranged from as low as $3.57 \mathrm{mg}$ in spinach to $21.0 \mathrm{mg}$ in shepu (Table 3). Amaranth and kilkeerai were similar with 11 and $14 \mathrm{mg}$ respectively. Comparable values for amaranth and spinach has been reported by Bhaskarachary et al. ${ }^{[29]}$ and Granado et al. ${ }^{[30]}$ Comparison between the cooked and the raw greens revealed that cooking caused considerable increase in all samples. The percent increase ranged from 7 to $38 \%$ on wet basis. Calculations on dry basis to eliminate the differences due to moisture showed that the extent of increase ranged from $8-68 \%$. Increase in the carotene content of cooked samples has been reported by Granado et al. ${ }^{[30]}$ and Park et al. ${ }^{[31]}$ and they attributed this to increased extractability on cooking and/or due to destruction of enzymes which otherwise caused carotene degradation. Ang et al. ${ }^{[32]}$ and Eheart and Gott $^{[18]}$ however, reported an insignificant loss of carotene due to microwave and conventional cooking.

The sensory attributes of cooked greens were analyzed using ranking test and QDA. The attributes analyzed were color, appearance, aroma, taste, and texture. The results of ranking test and QDA are presented in Table 4 and Fig. 1 respectively. The results of these tests indicate that color was the only attribute that was affected to a significant extent $(p \leq 0.05)$. Comparison between conventional and microwave methods showed that in case of amaranth and shepu, color of microwave cooked greens was preferred more than conventional and the reverse was true for kilkeerai and spinach, however they were not statistically significant. The color of the pressure cooked amaranth, kilkeerai, and shepu had the highest ranking and low mean scores which showed that the color of the greens that resulted due to this cooking method was liked the least. The reason for this obviously is the change in the color from green to olive green due to the formation of pheophytin. The high temperature attained in pressure cooking $\left(121^{\circ} \mathrm{C}\right)$, the time taken for cooking and inability of volatile acids to escape are probably the factors that has lead to increased formation of pheophytin. Aroma of all the cooked samples were similar in amaranth whereas in shepu and spinach the pressure cooked samples were considered relatively inferior and that of conventionally cooked and microwave cooked were similar. The difference in the aroma of the greens however was not statistically significant. Texture of pressure cooked kilkeerai and shepu had a lower ranking but was not statistically significant and was followed by similar rankings of conventionally cooked and microwave cooked samples. In case of amaranth and shepu the texture 
Table 4. Result of rank sum analysis.

\begin{tabular}{lcccc}
\hline & & \multicolumn{3}{c}{ Total of ranks marked } \\
\cline { 3 - 5 } Attributes & No. of panelists ${ }^{\mathrm{a}}$ & Con & Pre & Mic \\
\hline Amaranth & & & & \\
$\quad$ Color & 19 & 35.0 & $48.0^{\mathrm{b}}$ & 29.0 \\
Aroma & 17 & 33.0 & 36.0 & 33.0 \\
Texture & 18 & 32.5 & 34.0 & 41.5 \\
Overall quality & 20 & 37.0 & 46.5 & 36.5 \\
Kilkeerai & & & & \\
Color & 18 & 30.5 & $45.0^{\mathrm{b}}$ & 32.5 \\
Aroma & 18 & 25.5 & 36.0 & $40.5^{\mathrm{b}}$ \\
Texture & 18 & 34.5 & 29.0 & 35.0 \\
Overall quality & 18 & 33.0 & 35.0 & 40.0 \\
Shepu & & & & \\
Color & 20 & 38.5 & $50.5^{\mathrm{b}}$ & 31.0 \\
Aroma & 16 & 29.5 & 39.0 & 27.5 \\
Texture & 19 & 38.5 & 30.5 & 35.0 \\
$\quad$ Overall quality & 19 & 33.5 & 45.5 & 35.0 \\
Spinach & & & & \\
Color & 20 & $29.0^{\mathrm{b}}$ & 38.0 & 41.0 \\
Aroma & 18 & 30.0 & 42.0 & 36.0 \\
Texture & 19 & 27.0 & 40.0 & 37.0 \\
Overall quality & 20 & $29.0^{\mathrm{b}}$ & 33.5 & 35.5 \\
\hline Conyyyy & & & & \\
\hline
\end{tabular}

Con-conventionally cooked; Pre-pressure cooked; Micmicrowave cooked.

${ }^{\mathrm{a}}$ Variation in no. of panelists is due to editing.

${ }^{\mathrm{b}}$ Significantly different at $5 \%$ level.

of conventionally cooked sample was considered to be better and was followed by pressure cooked amaranth and microwave cooked spinach. Taste of microwave cooked amaranth was considered best. In kilkeerai, taste and overall quality of all the three different cooked samples were similar. The taste of shepu was acceptable to a lesser extent when compared with the other greens. However, the taste of microwave cooked shepu (Fig. 1c) was considered better among the three. In spinach, the taste and overall quality was considered to be better in conventionally cooked sample. Eheart and Gott ${ }^{[18]}$ and Kylen et al. ${ }^{[19]}$ showed that the conventional cooking and microwave cooking had similar effect on the sensory attributes of spinach. Klein et al. ${ }^{[21]}$ however reported that total palatability of microwave cooked spinach was significantly $(p \leq 0.05)$ better than conventionally cooked.

\section{CONCLUSION}

It can be concluded that while cooking methods do not influence the nutritional composition of green leafy vegetables to a significant extent, they do affect the 

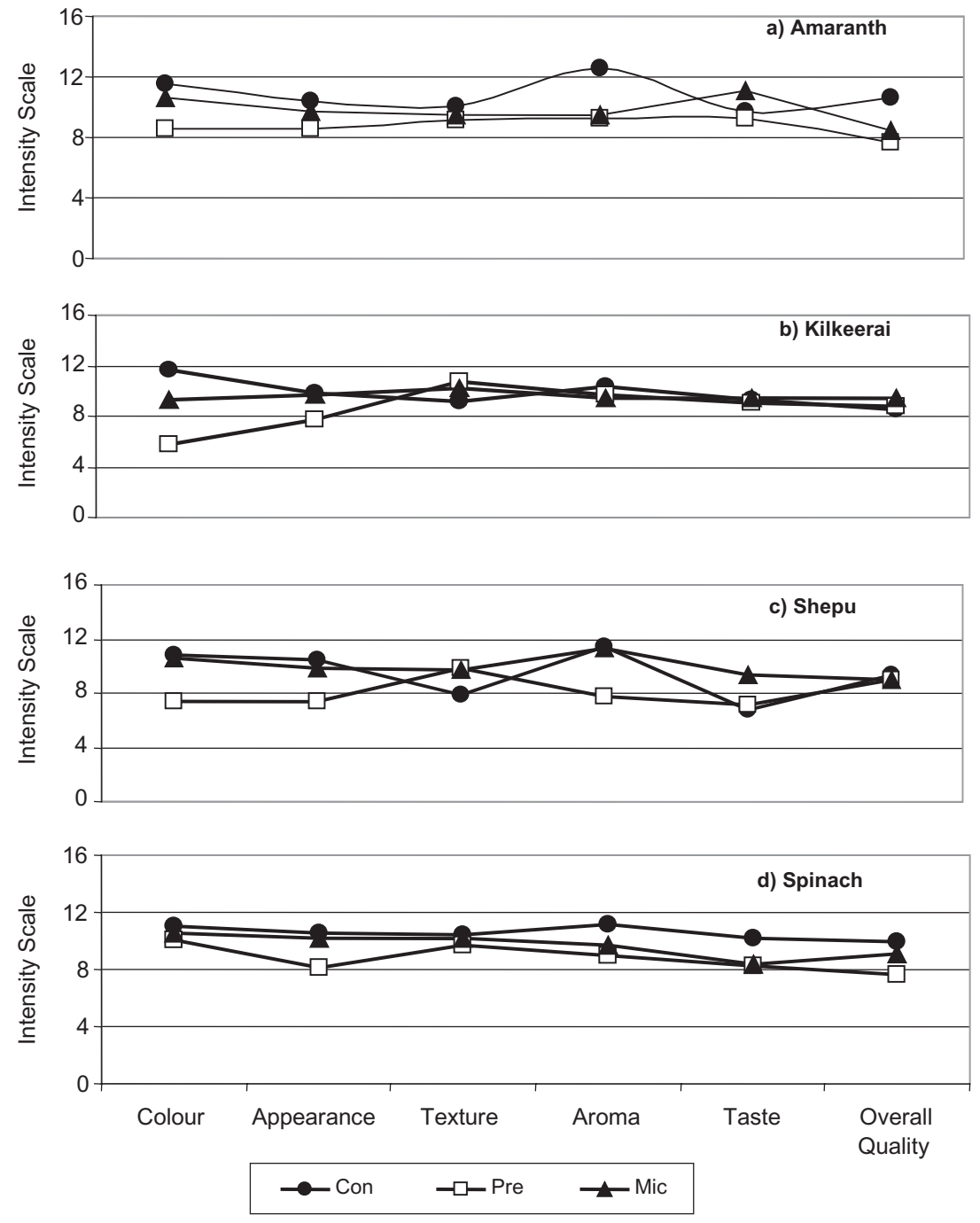

Figure 1. Mean scores of profile test of cooked greens (Con-conventionally cooked, Prepressure cooked, Mic-microwave cooked).

sensory quality. Microwave cooking was found to be similar to conventional method whereas pressure cooking affected certain sensory parameters of green leafy vegetables.

\section{ACKNOWLEDGMENTS}

Financial support from Council of Scientific and Industrial Research, New Delhi, for this investigation is gratefully acknowledged. 


\section{REFERENCES}

1. Hughes, O.; Marion, B. Introductory Foods, 5th Edn; The Mac Millan Co.: London, 1970; 59-85.

2. Duckworth, R.B. Fruits and Vegetables; Pergomon Press: Oxford, 1966; $142-159$.

3. Svanberg, S.J.M.; Nyman, E.M.G.L. Effects of boiling and storage on dietary fiber and digestible carbohydrates in various cultivars of carrots. J. Sci. Food Agri. 1997, 73, 245-254.

4. Schneeman, B.O. Dietary fiber. Food Tech. 1989, 43, 133-139.

5. Prakash, D.; Joshi, B.D.; Pal, M. Vitamin C in leaves and seed oil composition of the Amaranthus species. Int. J. Food Sc. Nutr. 1995, 46, 47-51.

6. Dikshit, S.N.; Udipi, S.A.; Rao, A.; Manohar, V. Separation of carotenoid and estimation of beta-carotene content of selected Indian food and food preparations by HPLC. J. Food Sci. Technol. 1988, 25, 39-41.

7. Friedman, M. Nutritional value of proteins from different food sources - a review. J. Agri. Food Chem. 1996, 44, 6-29.

8. Ifon, E.T.; Bassir, O. The nutritive value of some Nigerian leafy green vegetables-part I: vitamin and mineral contents. Food Chem. 1979, 4, $263-267$.

9. Mongeau, R.; Saswar, G.; Peace, R.W.; Brassard, R. Relationship between dietary fiber levels and protein digestibility in selected foods as determined in rats. Plant Foods for Human Nutr. 1989, 39, 45-51.

10. AOAC. Official Methods of Analysis, 13th Ed.; Association of Official Analytical Chemists: Washington, DC, 1981.

11. NIN. A Manual of Laboratory Techniques; National Institute of Nutrition, ICMR: Hyderabad, India, 1983.

12. Asp, N.G.; Johansson, C.G.; Hallmer, H.; Siljestrom, M. Rapid enzymatic assay of insoluble and soluble dietary fiber. J. Agri. Food Chem. 1983, 31, 476-481.

13. Bernard, O.L. Hawk's Physiological Chemistry, 14th Ed.; Tata McGraw-Hill Publishing Co., Ltd.: New Delhi, India, 1965; 1263-1265.

14. Rao, B.S.N.; Prabhavathi, T. An in vitro method for predicting the bioavailability of iron from foods. Am. J. Clin. Nutr. 1978, 31, 169-175.

15. Ranganna, S. Handbook of Analysis and Quality Control for Fruit and Vegetable Products, 2nd Ed.; Tata McGraw Hill Publishing Co. Ltd.: New Delhi, India, 1986; 87-96.

16. Kramer, A. Revised tables for determining significance of differences. Food Technol. 1963, 17 (12), 1596-1597.

17. Zook, K.; Wessman, C. The selection and use of judges for descriptive panels. Food Technol. 1977, 31 (11), 56-61.

18. Eheart, M.S.; Gott, C. Conventional and microwave cooking of vegetablesascorbic acid and carotene retention and palatability. J. Am. Dietet. Assoc. 1964, 44, 116-119.

19. Kylen, A.M.; Charles, V.R.; Mc Grath, B.H.; Schleter, J.M.; West, L.C.; Van Duyne, F.O. Microwave cooking of vegetables: ascorbic acid retention and palatability. J. Am. Dietet. Assoc. 1961, 39, 321-326. 
20. Noble, I.; Hanig, M.M. Ascorbic acid and dehydroascorbic acid content of raw and cooked vegetables. Food Res. 1948, 13, 461-471.

21. Klein, B.P.; Kuo, C.H.Y.; Boyd, B. Folacin and ascorbic acid retention in fresh raw, microwave and conventionally cooked spinach. J. Food Sci. 1981, 46, 640-641.

22. Gopalan, C.; Ramashastri, B.V.; Balasubramanian, S.C.; Rao, B.S.N.; Deosthale, Y.G.; Pant, K.C. Nutritive Value of Indian Foods; National Institute of Nutrition, ICMR: Hyderabad, India, 1996.

23. Ifon, E.T.; Bassir, O. The nutritive value of some Nigerian leafy green vegetables-part II: the distribution of protein, CHO, (including ethanolsoluble simple sugar), crude fat, fiber and ash. Food Chem. 1980, 5, 231-235.

24. Marlett, J.A.; Vollendorf, N.W. Dietary fiber content and composition of vegetables determined by two methods of analysis. J. Agri. Food Chem. 1993, 41, 1608-1612.

25. Mc Dougall, G.J.; Morrison, I.M.; Stewart, D.; Hillman, J.R. Plant cell walls as dietary fiber: range, structure, processing and function. J. Sci. Food Agri. 1996, 70, 133-150.

26. Chawla, S.; Saxena, A.; Seshadri, S. In vitro availability of iron in various green leafy vegetables. J. Sci. Food Agri. 1988, 46, 125-127.

27. Reddy, N.S.; Malewar, V.G. Bio-availability of iron form spinach (Spinacia oleracea) cultivated in soil fortified with graded levels of iron. Plant Foods for Human Nutr. 1992, 42, 313-318.

28. Rangarajan, A.; Kelly, J.F. Iron bioavailability from Amaranthus species I: in vitro dialyzable iron for estimation of genetic variation. J. Sci. Food Agri. 1988, 76, 267-273.

29. Bhaskarachary, K.; Rao, D.S.S.; Deosthale, Y.G.; Reddy, V. Carotene content of some common and less familiar foods of plant origin. Food Chem. 1995, 45, 189-193.

30. Granado, F.; Olmedilla, B.; Blanco, I.; Rojashidalgo, E. Carotenoid composition in raw and cooked spanish vegetables. J. Agri. Food Chem. 1992, 40, 2135-2140.

31. Park, Y.W. Effect of freezing, thawing, drying and cooking on carotene retention in carrots, broccoli and spinach. J. Food Sci. 1987, 52, 1022-1025.

32. Ang, C.V.; Chang, C.M.; Fray, A.E.; Livingston, G.H. Effects of heating methods on vitamin retention in six fresh or frozen prepared food product. J. Food Sci. 1975, 40, 997-1003. 


\section{Request Permission or Order Reprints Instantly!}

Interested in copying and sharing this article? In most cases, U.S. Copyright Law requires that you get permission from the article's rightsholder before using copyrighted content.

All information and materials found in this article, including but not limited to text, trademarks, patents, logos, graphics and images (the "Materials"), are the copyrighted works and other forms of intellectual property of Marcel Dekker, Inc., or its licensors. All rights not expressly granted are reserved.

Get permission to lawfully reproduce and distribute the Materials or order reprints quickly and painlessly. Simply click on the "Request Permission/ Order Reprints" link below and follow the instructions. Visit the U.S. Copyright Office for information on Fair Use limitations of U.S. copyright law. Please refer to The Association of American Publishers' (AAP) website for guidelines on Fair Use in the Classroom.

The Materials are for your personal use only and cannot be reformatted, reposted, resold or distributed by electronic means or otherwise without permission from Marcel Dekker, Inc. Marcel Dekker, Inc. grants you the limited right to display the Materials only on your personal computer or personal wireless device, and to copy and download single copies of such Materials provided that any copyright, trademark or other notice appearing on such Materials is also retained by, displayed, copied or downloaded as part of the Materials and is not removed or obscured, and provided you do not edit, modify, alter or enhance the Materials. Please refer to our Website User Agreement for more details.

\section{Request Permission/Order Reprints}

Reprints of this article can also be ordered at http://www.dekker.com/servlet/product/DOI/101081JFP200033079 